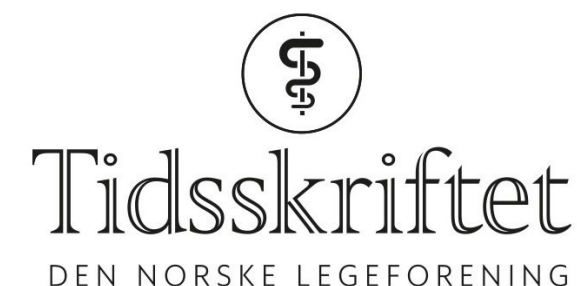

\title{
Rettelse: En kvinne i 20-årene med urininkontinens
}

RETTELSE

THOMAS F. NAESS-ANDRESEN

ANNIKEN HASLUND

ANNA BJERRE

WOLFGANG MICHAEL EICHSTETTER

GUNNAR UWE WALTHER EBNER

Tidsskr Nor Legeforen 2018; 138: 1739-43.

I Tidsskriftet nr. 18/2018 på s. 1739 skal det stå: Hun ble behandlet med piperacillin/tazobaktam intravenøst...

Vi beklager feilen, den er rettet på nett.

Publisert: 7. november 2018. Tidsskr Nor Legeforen. DOI: 10.4045/tidsskr.18.0871

(C) Tidsskrift for Den norske legeforening 2020. Lastet ned fra tidsskriftet.no 